\title{
WILLIAM WHISTON, THE UNIVERSAL DELUGE, AND A TERRIBLE SPECTACLE
}

\section{Roomet Jakapi}

\begin{abstract}
William Whiston (1667-1752) was an English divine, mathematician and astronomer. His works nicely reveal the close relationship between science and religion in the Early Modern period. The paper aims to characterise Whiston's way of thinking in the light of his Astronomical Principles of Religion, Natural and Reveal'd (1717).
\end{abstract}

Keywords: William Whiston, history of science, cosmology, biblical exegesis.

William Whiston (1667-1752), a British divine, mathematician and astronomer, is a remarkable figure in the history of science, religion and, perhaps, philosophy. In this paper I want to briefly characterise Whiston's way of thinking. I will focus on the relation between the scientific and religious side of his thought. These, sometimes hardly separable sides or aspects do naturally belong together in most of his work.

Whiston's first and apparently most influential book A New Theory of the Earth, From its Original, to the Consummation of all Things. Wherein the Creation of the World in Six Days, the Universal Deluge, And the General Conflagration, As laid down in the Holy Scriptures, Are Shewn to be perfectly Agreeable to Reason and Philosophy was published in 1696. As the title suggests, Whiston here provided arguments for the truth of the biblical stories of Creation, the Noachian Deluge, and so on. He believed that the Bible gives a true historical description (albeit not a "nice and philosophical", that is, scientific account) of these events. He opposed the allegorical interpretation of the Bible advanced by Thomas Burnet ${ }^{1}$, and appeared simultaneously as an exegete and a physical scientist. Whiston was and remained a Newtonian scientist-theologian (Force 1985).

In 1702 he succeeded Sir Isaac Newton (1642-1727) as Lucasian Professor of Mathematics at the University of Cambridge. He was assigned to this post by Newton himself. It is worth mentioning, however, that he never became a member of the Royal Society. 


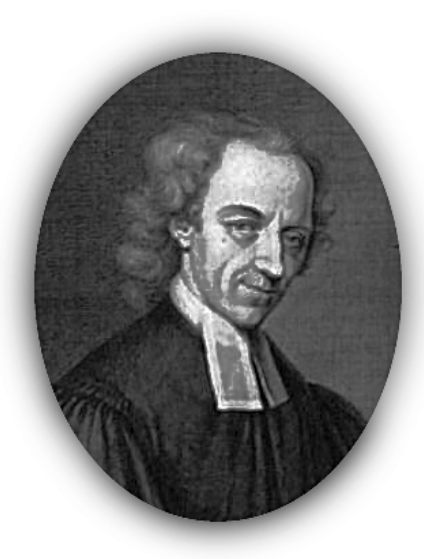

William Whiston (1667-1752)

Robert Boyle (1627-92), a pious Christian and an outstanding promoter of the new experimental science, established a series of public lectures (known as 'The Boyle Lectures') in defence of natural and revealed religion against atheism. The lectures were delivered by distinguished academics from 1692 to 1732. Whiston was the Boyle lecturer in 1707. His contribution to this magnificent project was published as The Accomplishment of Scripture Prophecies.

Whiston became a heretic inasmuch as he, like Newton, rejected the Athanasian doctrine of the Trinity. However, unlike Newton he publicly professed his antitrinitarian views and soon received punishment. In 1710 he was expelled from the university. After this unfortunate event he moved to London where he gave influential public lectures both on scientific and religious issues and published several works on these subjects over the years (see Force 1985: 18-25).

As regards to his general views on God, man and world, Whiston is a typical figure in the 17th- and early 18 th-century science, or rather, "natural philosophy", as it was called. The "natural philosophers" of the Early Modern period, the founders of modern natural science, were typically religious people. They lived in an intellectual world largely shaped by biblical beliefs and church doctrines. Newton, Boyle and other prominent members of the Royal Society conceived of "natural philosophy" as confirming (not contradicting or undermining) the Christian faith. The same applies to Whiston.

Freethinkers (e.g. Charles Blount and Anthony Collins), who challenged or ridiculed the great biblical narratives or even dared to question the divine origin and authority of the Bible, were commonly regarded as dangerous dissenters (and not necessarily as serious scholars). 
The "natural philosophers" typically believed that the world was created, and that it was created less than 10,000 years ago. ${ }^{2}$ Likewise, they believed that the human species was created. For them, bodily death was not the end of the story. It was quite natural and normal those days seriously to believe in the general Resurrection of the Dead and the Last Judgement (see Almond 1994, Ch. 4). They seem to have sincerely hoped to obtain eternal life and happiness in the world to come. Alternative beliefs were considered as heretical, sinful, and dangerous.

So it is no wonder that people like Newton, Whiston or Boyle made sincere efforts to accommodate their scientific findings to their basic religious convictions and the general religious framework of thought (see Israel 2001: 456-7, 461, 518-20). This is not to say, however, that they obediently adhered to every single doctrine of the Church of England. Some "natural philosophers" secretly held heterodox positions. Whiston, as already said, suffered for disclosing his religious unorthodoxy.

In any case, the "natural philosophy" of the Early Modern period was, in many respects, closely related to religious issues which the "natural philosophers" took very seriously.

Whiston's thought is a characteristic example of what has been called the "rapprochement' between Newtonian science and religion" (Force 1985: xxi, 2, 10). I have chosen one of his best known books, the Astronomical Principles of Religion, Natural and Reveal'd, to illustrate this interesting development in the history of ideas.

Already the title reveals the character of Whiston's thought. In our times, astronomy is generally considered a branch of natural science, and thereby more or less severely opposed to such nonscientific fields as religion or the so-called pseudo-sciences. Given the authority and extent of scientific thinking (proper and popular) in the contemporary Western world, the mixture of astronomy and religion, astronomy and astrology, and so on, is often regarded as a work of simple-minded, illiterate, or malicious people. This, of course, was not the case in Whiston's time. In his book, science and religion were joined in matrimony. In the following I will point out some highlights of that happy marriage. 
The first five parts of the book describe the "system of the world" based upon Newton's mechanical principles. The "rapprochement" between science and religion becomes evident in parts VI and VII of the book, dealing, respectively, with the "Important Principles of Natural Religion" and the "Important Principles of Divine Revelation". The former principles, that is, the immateriality and immortality of human souls, as well as the existence and attributes of God, are all derived from the "true System of the World".

Thus it follows from this system that "the World has not been from all Eternity": it was created by God. The "Matter of the Universe" was created "out of Nothing" by "the Almighty Power of God" (Whiston 1717: 108). God is an eternal being, existing "without any Cause or Beginning whatsoever" (ibid: 110). God is a free agent (ibid: 114). He is intelligent and omniscient (ibid: 116), omnipresent (ibid: 120), good and beneficent (ibid: 124).

Whiston explains God's relation to the created physical world. God operates in the physical world by means of "immechanical" powers:

From the foregoing System we learn, that God, the Creator of the World, does also exercise a continual Providence over it, and does interpose his general, immechanical, immediate Power, which we call the Power of Gravity, as also his particular immechanical Powers of Refraction, of Attraction, and Repulse, \& c. in the several particular Cases of the Phænomena of the World; and without which all this beautiful System would fall to Pieces, and dissolve into Atoms. On which Occasion, the Apostolical Constitutions speak as agreeably to Philosophy as to Religion, when they say, The whole World is held together by the Hand of God. (Whiston 1717: 111f)

God is present and acts everywhere. He is an immaterial being continuously acting upon matter:

We learn farther from this System, that the Supreme God, the Maker and Governor of the Universe, is, in his own Nature and Substance, Immaterial. This is also a most direct Consequence from the true System of the World, whereby it has appear'd that God, the only Author of the Power of Gravity, does act, and is present to the inmost Parts of all solid Bodies; nay that he is 
William Whiston, the Universal Deluge, and a Terrible Spectacle

equally present, and equally acts in those inmost Parts of all solid Bodies, as in any empty Spaces themselves, and withal that this Action upon all Bodies is not like to material and mechanical Impulse, which is ever on the Surface only; but penetrates those Bodies themselves, and every where causes a Gravitation, not according to the Surface, but according to the entire solid Content, or Quantity of the real Matter it self, contain'd in every one of those Bodies. This Property is highly remarkable, and of great Consequence against those who are unwilling to allow any real Being but Matter in the Universe. (Whiston 1717: 123)

In part VII, Whiston addresses a number of issues pertaining to the "divine revelation". Thus, for example, he aims to show that "the Sacred Accounts of the Creation of the World out of a Chaos" (ibid: 139) and "the Sacred Chronology, or Scripture Account of the Antiquity of the World, and its Duration since the Deluge" are consistent with the "true System of the World" (ibid: 141). These issues were exhaustively analysed in the New Theory of the Earth.

Whiston interpreted the chaos out of which the Earth was created (on his reading of Genesis) as an atmosphere of a comet. In the process of creation God formed this comet into a planet, that is, the present Earth (ibid: 139).

Whiston, like Edmund Halley (1656-1742) before him, was searching for the physical cause of the Deluge. Both men believed that God acted through and carried out his providential plans by means of natural causes (Schechner 1997: 162, 189-194). The more or less exact time when the Flood occurred, as well as the age of the world, was to be determined:

the best ways of Determination we now have of the Age of the World, whether from Prophane History, or the Phænomena of Nature, do very well agree to the Sacred Chronology, and confirm us in the Belief that the Earth has not been in its present State above 6000 or 7000 years; and that since the general Flood, there have scarce yet passed 5000 Years; according to the Sacred Chronology thereto relating. (Whiston 1717: 142) 
Following Halley, Whiston claimed that the Deluge was caused by a close approach of a comet to the Earth (Schechner 1997: 163-4, 190; Force 1985: 48). On the basis of his precise calculations (see Schechner 1997: 192, 298), he referred to a particular comet:

Indeed the Solution of this most remarkable Phænomenon of an Universal Deluge /.../ is now, I think become so plain, evident, and certain, from the Phænomena of Comets, with their Atmospheres and Tails, now fully discovered; especially from the particular Circumstances, and Periods of the last most famous Comet of 1680 / 1, which appears to have been the Physical Cause of the same Deluge. (Whiston 1717: 146f)

It may seem unbelievable or ridiculous to us but in the 17th- and early 18th-century cosmologies the location of hell in the universe was a serious issue (see Almond 1994, Ch. 4). This horrible place of punishment could be located beneath the earth, as the tradition had it, or elsewhere, for example, on the sun, as the "Copernican Anglican" Tobias Swinden has pointed out (Almond 1994: 125f). It seemed obvious that the torment of the wicked following the Last Judgment would have to take place somewhere. Determining the location of hell presupposed both theological (exegetical) and scientific skills and knowledge. Different scientific positions and considerations contributed to the emergence of different theories about the final destination of the wicked people.

Whiston's view on this issue relies on the juxtaposition of the biblical descriptions of hell and scientific evidence regarding comets, all this considered against the background of the "true System of the World". His interpretation of the "Important Principles of Divine Revelation" ends with the following curious mixture of physico-theological reasoning and prophetic admonition:

I observe, that the Sacred Accounts of Hell, or of the Place and State of Punishment for wicked Men after the general Resurrection, is agreeable not only to the Remains of ancient profane Tradition, but to the true System of the World also. This sad State is in Scripture describ'd as a State of Darkness, of outward Darkness, of blackness of Darkness, of Torment and Punishment for Ages, or for Ages of Ages, by Flame, or by Fire, or by Fire and Brimstone, with Weeping and Gnashing of Teeth; where the 
Smoak of the Ungodly's Torment ascends up for ever and ever; where they are Tormented in the Presence of the Holy Angels, and in the Presence of the Lamb; when the Holy Angels shall have separated the Wicked from among the Just, and have cast them into a Furnace of Fire. Now this Description does in every Circumstance, so exactly agree with the Nature of a Comet, ascending from the Hot Regions near the Sun, and going into the Cold Regions beyond Saturn, with its long smoaking Tail arising up from it, through its several Ages or Periods of revolving, and this in the Sight of all the Inhabitants of our Air, and of the rest of the System; that I cannot but think the Surface or Atmosphere of such a Comet to be that Place of Torment so terribly described in Scripture, into which the Devil and his Angels, with wicked Men their Companions, when delivered out of their Prison in the Heart of the Earth, shall be cast for their utter Perdition or second Death; which will be indeed a terrible but a most useful Spectacle to the rest of God's rational Creatures; and will admonish them above all Things to preserve their Innocense and Obedience; and to fear him who is thus able to destroy both Soul and Body in Hell. (Whiston 1717: 155f) ${ }^{3}$

This powerful statement by Whiston is a fine exemplification of the close relationship between the Early Modern science and religion.

\section{Comments}

${ }^{1}$ Burnet's Sacred Theory of the Earth was published in 1690. For discussions of this controversy, see Force 1985, Ch. 2; Almond 1994: 127; Schechner 1997: 162f.

${ }^{2}$ One of the many interesting reflections on the subject is to be found in George Berkeley's Alciphron: or, the Minute Philosopher (1732), dialogue VI, sects. 21-23 (Berkeley 1948-1957: 3: 258-265).

${ }^{3}$ For accounts of Whiston's theory of hell, see Almond 1994: 128f; Schechner 1997: $193 f$.

\section{References}

Almond, Philip C. 1994. Heaven and Hell in Enlightenment England. Cambridge: Cambridge University Press. 
Berkeley, George 1948-1957. The Works of George Berkeley Bishop of Cloyne. Luce, A. A. and Jessop, E. T. (eds.). London \& Edinburgh: Thomas Nelson and Sons.

Force, James E. 1985. William Whiston. Honest Newtonian. Cambridge: Cambridge University Press.

Israel, Jonathan I. 2001. Radical Enlightenment. Philosophy and the Making of Modernity 1650-1750. Oxford: Oxford University Press.

Schechner, Sara J. 1997. Comets, Popular Culture, and the Birth of Modern Cosmology. Princeton: Princeton University Press.

Whiston, William 1717. Astronomical Principles of Religion, Natural and Reveal'd. London. 